\title{
HIGHLY EFFICIENT EX VIVO GENE TRANSFER TO THE TRANSPLANTED HEART BY MEANS OF HYPOTHERMIC PERFUSION WITH A LOW DOSE OF ADENOVIRAL VECTOR
}

Carlo Pellegrini, $\mathrm{MD}^{\mathrm{a}}$

Anders Jeppsson, MD, $\mathrm{PhD}^{\mathrm{a}}$

C. Burcin Taner, MD

Timothy O'Brien, $\mathrm{MD}, \mathrm{PhD}^{\mathrm{b}}$

Virginia M. Miller, $\mathrm{PhD}^{\mathrm{c}}$

Henry D. Tazelaar, $\mathrm{MD}^{\mathrm{d}}$

Christopher G. A. McGregor, MB, FRCS ${ }^{\mathrm{a}}$
Background: Hypothermic conditions required for donor heart preservation may reduce gene-transfer efficiency. Experiments were designed to determine whether a perfusion technique could improve the efficiency of gene transfer to donor hearts. Methods: An adenoviral vector encoding $\beta$-galactosidase $\left(3.5 \times 10^{8}\right.$ plaque-forming units $)$ was infused into explanted rat hearts under 4 conditions (each $n=6)$ : $(1)$ the virus was diluted in $350 \mu \mathrm{L}$ of University of Wisconsin solution and infused as a high-pressure bolus into the coronary arteries of donor hearts through the aortic root; (2) the virus was diluted in $5 \mathrm{~mL}$ of University of Wisconsin solution and circulated by means of a peristaltic pump (flow, $0.75 \mathrm{~mL} / \mathrm{min}$ ) through the vasculature of the donor heart for $30 \mathrm{~min}$ utes; (3) $5 \mathrm{~mL}$ of viral solution was circulated as for group 2 for $15 \mathrm{~min}$ utes; and (4) $5 \mathrm{~mL}$ of viral solution was circulated for 5 minutes at a flow rate of $2.4 \mathrm{~mL} / \mathrm{min}$. Transduced hearts were transplanted into the abdomen of syngeneic rats, and transgene expression was assessed by means of immunoassay 4 days later. Results: The median $\beta$-galactosidase content was (1) $45.0 \mathrm{ng} / \mathrm{mg}$ protein (25th-75th percentile, 33-73 ng/mg), (2) $640 \mathrm{ng} / \mathrm{mg}$ protein (25th-75th percentile, $614-878 \mathrm{ng} / \mathrm{mg}$ ), (3) 493.8 $\mathrm{ng} / \mathrm{mg}$ protein (25th-75th percentile, $456-527 \mathrm{ng} / \mathrm{mg}$ ), and (4) 503.3 $\mathrm{ng} / \mathrm{mg}$ protein $(25 \mathrm{th}-75$ th percentile, $475-562 \mathrm{ng} / \mathrm{mg} ; \boldsymbol{P}<.01$ for group 2 vs group 1, and $P<.05$ for groups 3 and 4 vs group 1). Transgene expression was predominantly in myocytes and favored the subepicardial region of the right ventricle. Conclusion: Hypothermic perfusion of the donor heart with an adenoviral vector resulted in efficient transgene expression compared with that induced by a single bolus injection. (J Thorac Cardiovasc Surg 2000;119:493-500)
S veral obstacles must be overcome before widespread clinical application of gene therapy will be possible. The development of an effective and clinically applicable gene-delivery system resulting in exten-

From the Department of Surgery, ${ }^{a}$ Division of Endocrinology and Metabolism, ${ }^{\mathrm{b}}$ Department of Physiology and Biophysics, ${ }^{\mathrm{c}}$ and Department of Laboratory Medicine and Pathology, ${ }^{\mathrm{d}}$ Mayo Clinic and Foundation, Rochester, Minn.

Supported by grants from the Mayo Clinic and Foundation, the Bruce and Ruth Rappaport Program in Vascular Biology, and HL58080 (T.O.B.). Dr Carlo Pellegrini is a visiting scientist supported in part by a grant from Associazione Ami.Cardio, Pavia, Italy.

Received for publication June 21, 1999; revisions requested Sept 15, 1999; revisions received Oct 25, 1999; accepted for publication Oct 26, 1999

Address for reprints: C. G. A. McGregor, MB, FRCS, Mayo Clinic, 200 First St SW, Rochester, MN 55905 (E-mail: mcgregor.christopher@mayo.edu).

Copyright $\odot 2000$ by Mosby, Inc.

$0022-5223 / 2000 \$ 12.00+0 \quad \mathbf{1 2 / 1 / 1 0 4 0 3 4}$

doi:10.1067/mtc.2000.104034 sive and targeted transgene expression is crucial. In the specific setting of heart transplantation, gene transfer to the donor organ has been accomplished by either direct myocardial injection ${ }^{1}$ or intracoronary infusion of a variety of vectors, such as liposomes and genetically modified viral particles. ${ }^{2-5}$ Intramyocardial injection results in uneven, localized, transgene expression and incites a marked inflammatory response. Intracoronary infusion therefore represents a preferable method for gene delivery in the setting of transplantation.

Adenoviral vectors enter the cells through a 2-step process: (1) adhesion to a cell membrane receptor ${ }^{6}$ and (2) internalization mediated by $\alpha_{\mathrm{v}} \beta_{3}$ and $\alpha_{\mathrm{v}} \beta_{5}$ integrins. ${ }^{7,8}$ This latter step is energy dependent and occurs at normothermic conditions. Temperature significantly affects the efficiency of gene transfer in cultured endothelial and smooth muscle cells and thoracic aorta in culture. 9,10 Continuous hypothermic perfusion of donor hearts compared with hypothermic immersion 
storage can be used for preservation of donor organs. ${ }^{11,12}$ Therefore a modified hypothermic perfusion technique could be applied for gene delivery to donor hearts.

Experiments were designed to compare the efficiency of gene transfer and distribution of transgene expression after ex vivo circulation of an adenoviral vector through the coronary vasculature of donor hearts.

\section{Materials and methods}

Animals. Inbred male Lewis rats (270-330 g) were used as donors and recipients for syngeneic transplants. Procedures and handling of animals were reviewed and approved by the Institutional Animal Care and Use Committee of the Mayo Clinic and Foundation in compliance with "Principles of Laboratory Animal Care" formulated by the National Society for Medical Research and the "Guide for the Care and Use of Laboratory Animals" prepared by the Institute of Laboratory Animal Resources and published by the National Institutes of Health (National Institutes of Health publication No. 86-23, revised 1985).

Adenoviral vector. A serotype 5 adenovirus encoding for nonnuclear targeted Escherichia coli $\beta$-galactosidase under the control of the cytomegalovirus promoter was used in this study (AdCMVLacZ, provided by James Wilson, Institute for Gene Therapy, University of Pennsylvania). This vector has been rendered replication defective by replacing the entire E1a and most of the E1b regions of the adenoviral genome with the complementary DNA expression cassette. The recombinant virus was propagated in transformed human embryonic kidney carcinoma cells ("293 cells"), which constitutively express $\mathrm{E} 1$ proteins; isolated and purified as previously described ${ }^{13}$; and stored at $-70^{\circ} \mathrm{C}$ in a buffered solution of $10 \%$ glycerol until use. Viral titers were determined by means of plaque assay and expressed as plaque-forming units (PFU) per milliliter.

Donor operation. After anesthesia was obtained (pentobarbital sodium $70 \mathrm{mg} / \mathrm{kg}$ administered intraperitoneally), the donor rat was intubated and mechanically ventilated (model 683; Harvard Apparatus Inc, South Natick, Mass; tidal volume: $10 \mathrm{~mL} / \mathrm{kg}$, respiratory rate: 60 breaths $/ \mathrm{min}$ ). A median sternotomy was performed to expose the heart. After injection of $200 \mathrm{U}$ of aqueous heparin into the inferior vena cava, the innominate artery was cannulated with a 24 -gauge cannula, and the venae cavae and pulmonary veins were ligated en bloc with 4-0 silk. The aorta was tied distal to the cannula, and the heart was arrested with an infusion of cold University of Wisconsin solution (UWS) into the aortic root through the indwelling cannula (flow, $0.44 \mathrm{~mL} / \mathrm{min}$; duration, 5 minutes). After harvesting, the heart was stored in the same cardioplegic solution at $4^{\circ} \mathrm{C}$.

Experimental groups. The efficiency of adenovirus-mediated gene transfer was evaluated in 4 groups $(n=6$ in each group). Rats were randomly assigned to each group. In group $1,350 \mu \mathrm{L}$ of UWS containing $3.5 \times 10^{8} \mathrm{PFU}$ (titer, $1 \times 10^{9}$ $\mathrm{PFU} / \mathrm{mL}$ ) was infused as a high-pressure bolus (90-110 mm
$\mathrm{Hg}$ ) over 5 seconds into the coronary artery through the aortic root. The pulmonary artery was clamped during the infusion, and the virus was not flushed out at the end of $60 \mathrm{~min}$ utes of cold storage before performing the surgical procedure. In group 2, $5 \mathrm{~mL}$ of UWS containing $3.5 \times 10^{8} \mathrm{PFU}$ (titer, 7 $\times 10^{7} \mathrm{PFU} / \mathrm{mL}$ ) was circulated through the coronary vasculature of the donor organ for 30 minutes by means of a peristaltic pump (Rainin, Emeryville, Calif; Fig 1). The viral solution was infused into the donor organ through the cannula inserted into the aorta and was collected by a 14-gauge catheter placed into the pulmonary artery. Both catheters were connected by means of polyvinyl chloride tubing to the vial containing the viral solution. The flow rate was 0.75 $\mathrm{mL} / \mathrm{min}$. As determined in preliminary experiments $(\mathrm{n}=3)$ by means of a catheter inserted into the left common carotid artery, this rate generated a pressure of between 40 and 50 $\mathrm{mm} \mathrm{Hg}$ in the aortic arch. During the perfusion period, the container with the heart and the vial with the vector were kept on ice, and the temperatures of both solutions did not exceed $4^{\circ} \mathrm{C}$. The entrapment of air was not a problem. To help avoid this problem, the heart was kept vertical before starting the microperfusion and during circulation of the viral solution. In group 3 the effect of reducing the perfusion time and thus the number of passages of the vector through the donor organ was evaluated. The same volume of viral solution was circulated into the graft for 15 minutes at the same flow rate as in group 2. In group 4 the influence of flow rate and, consequently, pressure on transgene expression was assessed. In this latter group $5 \mathrm{~mL}$ of viral solution was circulated for 5 minutes at a flow rate of $2.4 \mathrm{~mL} / \mathrm{min}$, generating a pressure of between 70 and $80 \mathrm{~mm} \mathrm{Hg}$ in the aortic arch. In control animals ( $\mathrm{n}=3$ for the single bolus infusion group, low-flow perfusion groups, and high-flow perfusion group) virus-free UWS was administered.

Recipient operation. Heterotopic abdominal heart transplantation was performed by using standard microsurgical techniques. ${ }^{14}$ Animals were anesthetized by administration of intraperitoneal pentobarbital $(70 \mathrm{mg} / \mathrm{kg})$. In brief, the donor hearts were transplanted into the recipients by end-to-side anastomoses of the aorta and the pulmonary artery to the abdominal aorta and inferior vena cava, respectively, by using 10-0 monofilament sutures. During surgery, the heart was wrapped in gauze and kept cold by use of topical ice-cold saline solution. At reperfusion, appearance of each graft was graded on the basis of the color of the heart and the ventricular contractility (scale ranging from 1 to 5 , with grade 1 representing the worst). All rats received analgesia postoperatively (butorphanol tartrate $0.3 \mathrm{mg} / \mathrm{kg}$ administered subcutaneously) and recovered with oxygen in a warm environment. Function of the graft was checked daily by palpation of the beating transplanted heart.

Assessment of transgene expression. Four days after transplantation, the animals were anesthetized with an intraperitoneal injection of pentobarbital sodium $(70 \mathrm{mg} / \mathrm{kg})$, and the transplanted hearts were removed and flushed with saline solution. A midventricular section was cut, embedded in OCT compound (Miles Laboratories, Elkhart, Ind) and 


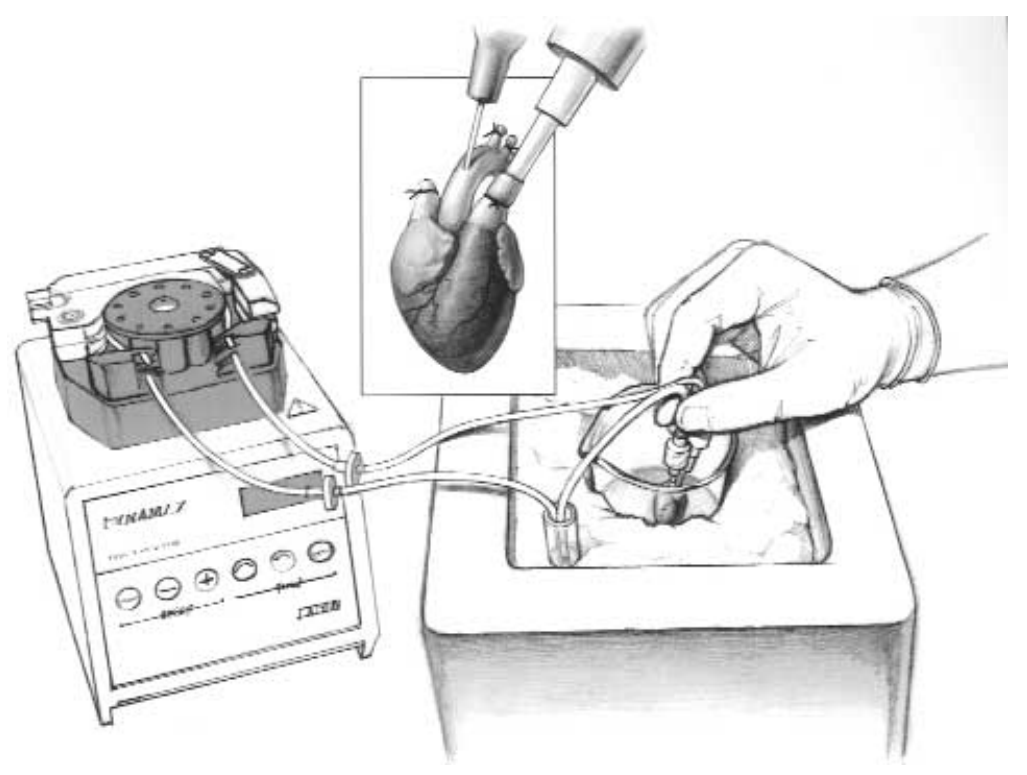

Fig 1. Illustration of the gene delivery system used in the current study. The solution containing the adenoviral vector was perfused from a vial through the vasculature of the donor heart and back to the vial by means of a peristaltic pump (left). The container with the heart immersed in UWS and the vial with the viral solution were kept on ice during the circulation time. The inset depicts the inflow and outflow catheters placed in the aorta and pulmonary artery, respectively.

snap-frozen in a liquid nitrogen-cooled 2-methylbutane bath for histologic evaluations and X-Gal staining. The remainder of the ventricles were snap-frozen in liquid nitrogen and then homogenized (Tekmar tissue homogenizer, Cincinnati, Ohio) for 3 minutes in ice-cold buffer $(100 \mathrm{mmol} / \mathrm{L}$ potassium phosphate [pH 7.8], 0.2\% Triton X-100 [Sigma Chemical Company, St Louis, Mo], and $200 \mathrm{mmol} / \mathrm{L}$ phenylmethylsulfonyl fluoride). The homogenates were centrifuged at $18,000 \mathrm{~g}$ for 10 minutes at $4^{\circ} \mathrm{C}$. The supernatant was collected and frozen at $-70^{\circ} \mathrm{C}$. Transgene expression was quantitatively assessed by means of an enzyme-linked immunosorbent assay (5' Prime $\rightarrow 3^{\prime}$; Prime Inc, Boulder, Colo). In brief, a rabbit polyclonal antibody specific to the $E$ coli $\beta$ galactosidase protein was coated onto polystyrene microwells. When transgene protein is present in tissue extracts added to the wells, it is captured and bound to the solid phase. Biotinylated secondary antibody to $\beta$-galactosidase then binds to immobilized primary antibody- $\beta$-galactosidase complex. The biotinylated antibody is quantified colorimetrically by incubation with streptavidin-conjugated alkaline phosphatase and color development substrate. Spectrophotometric analysis was performed on an automated analyzer (SPECTRAmax 340; Molecular Devices Corporation, Sunnyvale, Calif). By the same technique, transgene expression was also determined in recipient native organs (thigh skeletal muscle, testis, liver, lung, and heart) to evaluate the potential release into the systemic circulation and dissemination of the viral vector after restoration of the blood flow to the transplanted heart.
Additional aliquots of supernatant were used to assess total protein concentration by using bicinchoninic acid protein assay reagent (Pierce, Rockford, Ill).

Histology. The cellular distribution of transgene expression was evaluated by using X-Gal staining. Three $5-\mu \mathrm{m}$ thick cryostat sections were cut at $25-\mu \mathrm{m}$ intervals from the midventricular section. Sections were fixed in $1.25 \%$ glutaraldehyde for 15 minutes at $4{ }^{\circ} \mathrm{C}$ and then rinsed twice with phosphate-buffered saline solution (Gibco BRL, Gaithersburg, Md). Sections were stained in a solution of $500 \mu \mathrm{g} / \mathrm{mL} 5-$ bromo-4-chloro-3-indolyl- $\beta$-D-galactopyranoside (X-Gal; Boehringer Mannheim Corp, Indianapolis, Ind) for 4 hours at $37^{\circ} \mathrm{C}$ and then were rinsed in phosphate-buffered saline solution and counterstained with eosin. Blue-stained cells indicated the presence of $\beta$-galactosidase expression.

Adjacent slides were cut and stained with hematoxylin and eosin for routine histopathologic examination. Inflammation and ischemic damage were graded by an experienced cardiac pathologist blinded to the origin of the slides. Inflammation was scored on a scale comparable with the working formulation for cardiac rejection, ${ }^{15}$ whereas the following scale was used for ischemic damage: 0 , no ischemic damage; 1 , less than $5 \%$ of the area of the section; 2 , between $5 \%$ and $20 \%$ of the area; 3 , between $20 \%$ and $40 \%$ of the area; and 4 , more than $40 \%$ of the area.

To quantify transduction efficiency, 3 cross-sections of the heart from each rat were studied. Each region (subepicardium, midmyocardium, and subendocardium) was divided into 8 quadrants. For each quadrant, positive-staining cells and 
Table I. Operative data

\begin{tabular}{lccc}
\hline & Appearance score & Total ischemic time (min) & Ischemic damage score \\
\hline Group 1 (high-pressure bolus) & $3.33 \pm 0.82$ & $119.7 \pm 3.2$ & $1.0 \pm 0.89$ \\
Group 2 (low-pressure pump, 30 min) & $3.17 \pm 1.33$ & $132.2 \pm 6.3^{*}$ & $1.33 \pm 1.03$ \\
Group 3 (low-pressure pump, 15 min) & $3.17 \pm 1.33$ & $126.2 \pm 9.1^{\dagger}$ & $1.33 \pm 1.03$ \\
Group 4 (high-pressure pump, 5 min) & $1.33 \pm 0.52^{\ddagger}$ & $109.7 \pm 6.9$ & $1.67 \pm 1.21$
\end{tabular}

Values are shown as means \pm SD ( $n=6$ for each group). Statistical analysis was performed by using the analysis of variance test, followed by the Bonferroni post hoc test for paired comparison. Appearance score scale ranges from 1 to 5, with grade 1 representing the worst score. For ischemic damage score, see the "Methods" section. Total ischemic time is defined as implantation time plus time needed for preparation of microperfusion, circulation of viral solution, and recipient preparation. The implantation time was always less than 45 minutes.

"Denotes statistically significant difference versus groups 1 and $4(P<.05)$

'Denotes statistically significant difference versus group $4(P<.05)$.

Denotes statistically significant difference versus groups 1,2 , and $3(P<.05)$.

total cells were counted in one high-power $(\times 400)$ field in the subepicardial region, the midwall, and the subendocardial region. Transduction efficiency was calculated as the number of positively stained cells divided by the number of total cells in the quadrant considered. A total of 72 quadrants per heart were analyzed.

Statistical analysis. Results are expressed as medians and ranges when data did not follow a Gaussian distribution and variances were unequal. A nonparametric test (KruskalWallis) of analysis of variance, followed by the Dunn post hoc test for paired comparisons, was performed to evaluate differences in these cases. Results are expressed as means \pm standard deviation when data followed a Gaussian distribution. In these cases statistical analysis was performed by using an analysis of variance test, followed by the Bonferroni post hoc test for paired comparisons. Correlation was evaluated by the nonparametric Spearman test by using pooled data from all the groups. A $P$ value of $<.05$ was considered significant.

\section{Results}

Operative data. All perfused hearts resumed beating within 2 to 7 minutes after reperfusion, showing no differences between the groups. Hearts from the single bolus infusion group resumed beating in less than 1 minute after reperfusion. The appearance score was significantly lower in group 4 compared with the other groups despite a shorter total ischemic time (Table I). Total ischemic time was significantly longer in groups 2 and 3 compared with the other groups (Table I). There was no operative mortality. All transplanted hearts were beating at harvest (postoperative day 4).

Transgene expression. An 11- to 14-fold increase in transgene expression was observed in the transplanted hearts in which the virus was perfused compared with those undergoing the high-pressure bolus injection. The median $\beta$-galactosidase content, as determined by using an enzyme-linked immunosorbent assay, was
$45.0 \mathrm{ng} / \mathrm{mg}$ protein (25th-75th percentile, 33-73 $\mathrm{ng} / \mathrm{mg}$ ) in group $1,640 \mathrm{ng} / \mathrm{mg}$ protein (25th-75th percentile, $614-878 \mathrm{ng} / \mathrm{mg}$ ) in group $2,493.8 \mathrm{ng} / \mathrm{mg}$ protein (25th-75th percentile, $456-527 \mathrm{ng} / \mathrm{mg}$ ) in group 3, and $503.3 \mathrm{ng} / \mathrm{mg}$ protein (25th-75th percentile, $475-$ $562 \mathrm{ng} / \mathrm{mg})$ in group $4(P<.01$ for group 2 vs group 1 and $P<.05$ for groups 3 and 4 vs group 1; Fig 2). No differences were observed among the groups in which the vector was perfused into the donor organ.

There was no significant correlation between the level of transgene expression and either the total ischemic time (corresponding to the vector dwelling time; $r=$ $0.3322, P=.1127$ ) or the warm ischemic time (corresponding to the implantation time of the donor heart; $r$ $=-0.3456, P=.1601)$.

Transgene expression was not detected either in the transplanted hearts of control animals or in the native organs of any of the transduced animals.

Distribution of transgene expression and histologic characteristics. Myocytes, endothelial cells, and interstitial fibroblasts stained positively for $\beta$-galactosidase in the transduced hearts (Fig 3). Myocytes were the most frequently transduced cells, whereas only rare endothelial cells expressed the transgene. In $75 \%$ of the hearts from groups 2, 3, and 4, transgene expression was accentuated in the right ventricle compared with the left ventricle. Efficiency of transduction was significantly higher in the subepicardial region of groups 2 and 3 compared with group 1 . No statistically significant differences were observed in the efficiency of gene transfer in the midwall and the subendocardial regions of all groups (Table II).

Mild lymphocytic unifocal inflammatory cell infiltrates were observed in $3(12.5 \%)$ of 24 specimens (1 each for groups 1, 3, and 4).

Ischemia was characterized by patchy foci of coagulative necrosis surrounded by a zone of interstitial edema. Although groups 2 and 3 had a significantly 


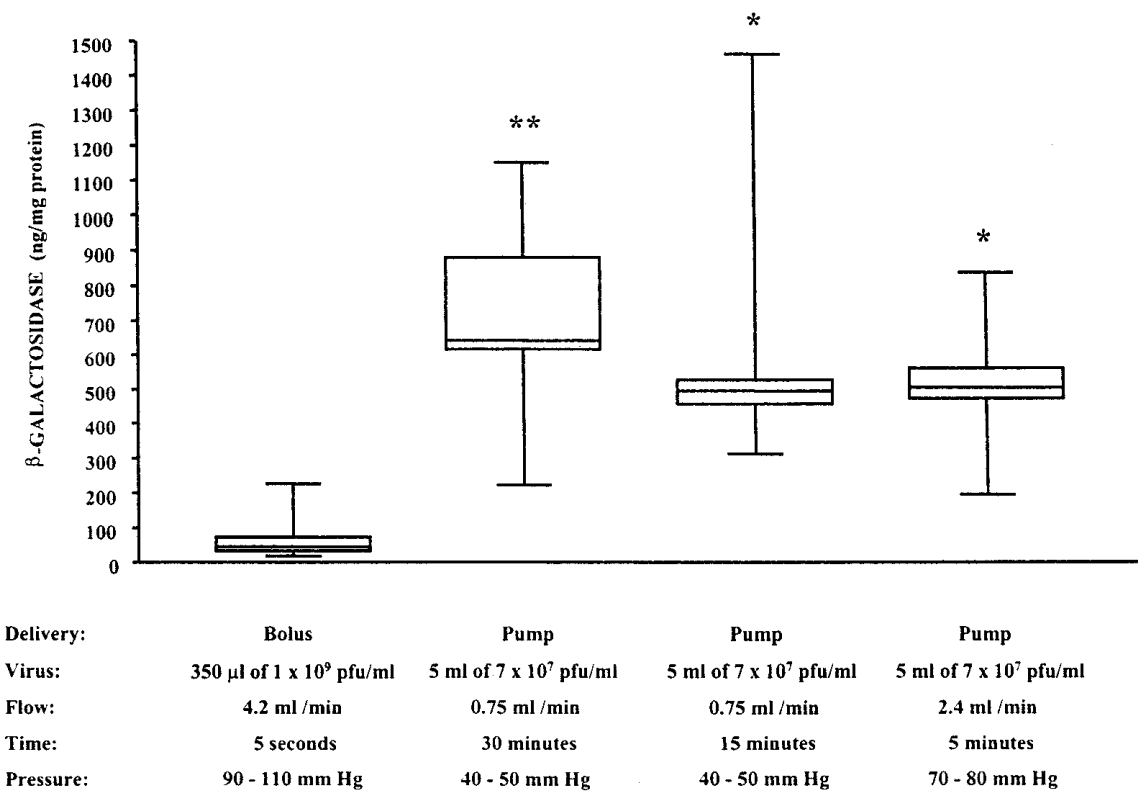

Fig 2. Administration of an adenoviral vector with a peristaltic pump increases transgene expression by 11 - to 14-fold. Asterisks denote statistically significant differences versus the bolus injection group, as determined by using the nonparametric analysis of variance test (Kruskal-Wallis; $P<.01$ for low-pressure 30-minute pump and $P<.05$ for low-pressure 15-minute and high-pressure 5-minute pumps). No difference in transgene expression was observed among the groups in which the vector was pumped through the donor hearts. Boxes represents 25 th median and 75th percentiles, whereas bars denote the range of $\beta$-galactosidase content ( $\mathrm{n}=6$ for each group).

longer total ischemic time compared with the other groups, the extent of ischemic damage was similar among the groups (Table I).

\section{Discussion}

The current study demonstrates highly efficient adenovirus-mediated gene transfer to donor hearts during hypothermic storage of the organ. The technique of perfusing the vector provided an 11- to 14-fold increase in transgene expression compared with the high-pressure bolus injection. This method allowed a 30 -fold reduction in the viral dose compared with that found in other reports, ${ }^{16,17}$ without affecting the level of transgene expression.

Gene transfer to the transplanted heart has been accomplished either by direct injection into the myocardium or by different techniques using intracoronary infusion of vectors, such as cationic and hemagglutining virus of Japan ${ }^{18}$ liposomes or replication-defective adenovirus. Gene transfer after direct intramyocardial injection is very efficient; however, transgene expression is localized in an area of 1 to 2 $\mathrm{mm}$ along the needle track. Wang and colleagues ${ }^{1}$ did not observe inflammation on the seventh postoperative day, but it is known from other in vivo studies ${ }^{19-21}$ that this delivery method is associated with an intense inflammatory response that, along with the spatial limitation of transgene expression, considerably limits the application of this technique.

Two methods of intracoronary infusion have been used to date. The first method consists of administration of the vector through the coronary vasculature as a rapid, highpressure, bolus injection. ${ }^{22,23}$ This method results in even distribution of transgene expression throughout the donor organ as compared with the direct injection; however, transduction efficiency is low, with fewer than 5\% of cells transduced. ${ }^{3}$ The second method uses a slow low-pressure infusion into the coronary vasculature. In the study from Shiraishi and colleagues, ${ }^{24}$ this method did not result in more efficient gene transfer over bolus injection, despite the use of a large amount of virus ( $5 \times$ $10^{10} \mathrm{PFU} / \mathrm{g}$ of tissue). Indeed, the content of recombinant $\beta$-galactosidase $(98.3 \pm 18.9 \mathrm{ng} / \mathrm{mg}$ protein) was similar to the level of transgene expression previously found after rapid bolus administration. Other authors, however, have achieved more efficient gene transfer with slow infusion. With an infusion time of 20 minutes, Brauner and colleagues ${ }^{16}$ increased the adenoviral vector uptake into the donor organ to $80 \%$ with the slowinfusion technique (compared with $10 \%$ with bolus 

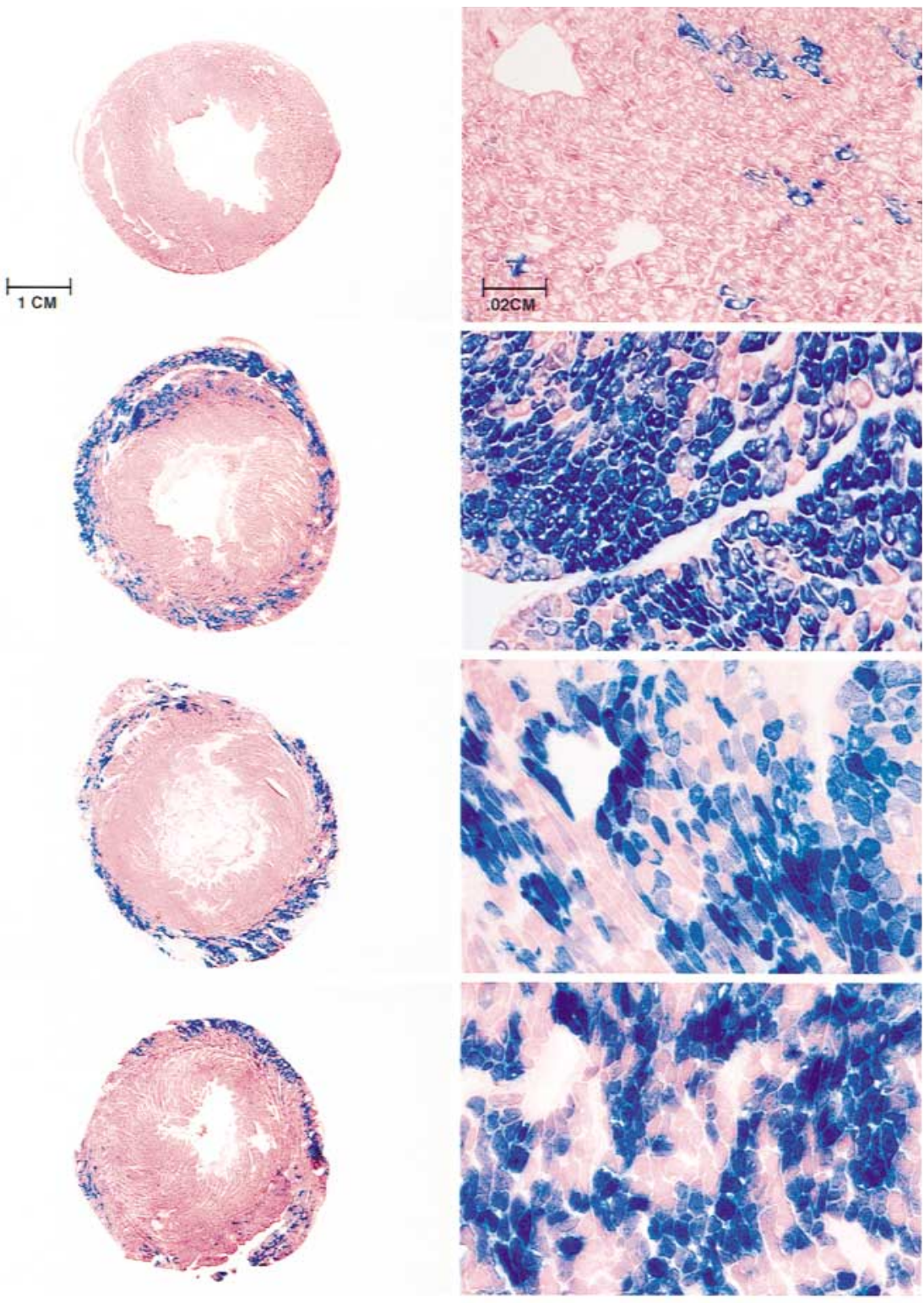

PH788759_1.DIGR

Fig 3. Light photomicrographs of sections of transplanted hearts from each experimental group (left panel, $\times 1$; right panel, $\times 50$ ). The blue-stained cells indicate $\beta$-galactosidase expression. All cell types (myocytes, endothelial cells, and interstitial fibroblasts) stained positively for the marker gene. Myocytes were the most frequently transduced cells, whereas only a few endothelial cells expressed the transgene protein. Staining is more accentuated in the subepicardial region and in the right ventricular wall.

injection), and the percentage of transduced cells rose to $25 \%$ and $40 \%$ in the subendocardial and subepicardial regions, respectively. ${ }^{17}$

In the current study the vector was initially perfused through the vasculature of the donor heart for $30 \mathrm{~min}-$ utes. This procedure resulted in highly efficient gene transfer when compared with bolus administration. Concerns about a prolongation of donor organ ischemia, however, led us to reduce the perfusion time. A $50 \%$ reduction to 15 minutes did not significantly affect the level of transgene expression. Although the need for hypothermic perfusion may complicate the system of gene delivery in practice, this will be necessary because a single bolus results in inefficient gene transfer. More important, in the present experiments a substantially smaller dose of adenoviral vector was 
Table II. Influence of different transduction methods on efficiency of adenovirus-medicated gene transfer to transplanted hearts

\begin{tabular}{|c|c|c|c|}
\hline & Subepicardial region & Midwall & Subendocardial region \\
\hline Group 1 (high-pressure bolus) & $16 \%(7.3-22)$ & $4.4 \%(3.8-7.7)$ & $2.6 \%(0.6-7.1)$ \\
\hline Group 2 (low-pressure pump, $30 \mathrm{~min}$ ) & $45 \%(40-52)$ & $14 \%(10-20)$ & $1.8 \%(1.4-2.8)$ \\
\hline Group 3 (low-pressure pump, $15 \mathrm{~min}$ ) & $49 \%^{*}(40-57)$ & $9.8 \%(6.1-12)$ & $2.0 \%(0.2-4.3)$ \\
\hline Group 4 (high-pressure pump, $5 \mathrm{~min}$ ) & $32 \%(27-44)$ & $19 \%(9.4-26)$ & $2.7 \%(1.2-14)$ \\
\hline
\end{tabular}

Values are shown as median (25th-75th percentiles); $n=6$ in each group.

${ }^{*}$ Statistically significant difference versus group 1, as determined by using the nonparametric analysis of variance test (Kruskal-Wallis; $P<.01$ for low-pressure 30 minute pump and $P<.05$ for low-pressure 15-minute pump).

used. Brauner and colleagues ${ }^{16}$ used a dose of $1 \times 10^{10}$ $\mathrm{PFU} / \mathrm{g}$ of tissue, which is about 30 times greater than the amount used in the current study $\left(3.5 \times 10^{8} \mathrm{PFU} / \mathrm{g}\right.$ tissue). Use of lower doses of adenoviral vectors may avoid some of the toxicity associated with this mode of gene transfer. Indeed, no significant inflammatory response was observed in the transduced hearts, which may have been due to the low viral dose used or the time point studied. In a nontransplant setting efficient gene transfer to the heart has been reported by means of intracoronary perfusion. ${ }^{25}$ In addition, this group has shown that the virus exposure time could be decreased by enhancement of microvascular permeability. ${ }^{26}$ Although these articles showed 96\% efficiency, it should be noted that the gene transfer was not accomplished under hypothermic conditions. Our results are therefore more applicable to the transplantation setting.

It is of interest that transgene expression was not evenly distributed in the transplanted hearts. The pattern correlated fairly closely with the observations after slow infusion of the vectors ${ }^{17}$ and was represented by efficient transgene expression in the perivascular areas and in the subepicardial region, which progressively decreased, moving toward the subendocardial region of the organ. Moreover, transgene expression appeared somewhat accentuated in the right ventricle compared with the left ventricle. (Atria were excluded from staining sections of the transplanted hearts.) The reason for this pattern of transgene expression is not clear. This is in contrast to the findings observed after either rapid or slow infusion of the vector. Indeed, no differences could be detected in transgene expression in different regions of the heart after rapid infusion of the vectors, ${ }^{23,27}$ whereas a significantly lower level of the transgene product was observed in the right ventricle after slow infusion. ${ }^{17}$ The predominant transduction of the right ventricle obtained with the current method may represent an important approach by gene therapy to pathologic processes that affect this chamber. Increasing the perfusion flow rate did not extend trans- gene expression to the midwall and subendocardial regions. Despite the use of a higher perfusion pressure, no alteration in the distribution of transgene expression in the graft could be observed. The appearance of the heart after reperfusion, however, did appear adversely affected by the high perfusion rate. No difference in the extent of ischemic damage could be detected in the experimental groups by means of routine histologic analysis.

A limitation of this study is that the transplanted heart was nonworking and unloaded. Thus no functional assessments were performed in these grafts. It is therefore important to carry out additional experiments in transplanted working hearts to establish the actual effect of this technique on ventricular function. In addition, these studies used a reporter gene, and future studies with physiologically relevant genes will be performed by using this method.

In summary, the current study demonstrates that high levels of transgene expression are achievable in transplanted hearts with the use of modest amounts of adenoviral vector in hypothermic conditions by perfusion of the virus through the coronary vasculature.

We thank Sharon Guy and Sandra Severson for their skillful technical assistance.

\section{REFERENCES}

1. Wang J, Ma Y, Knechtle SJ. Adenovirus-mediated gene transfer into rat cardiac allografts: comparison of direct injection and perfusion. Transplantation 1996;61:1726-9.

2. Ardehali A, Fyfe A, Laks H, Drinkwater DC Jr, Qiao JH, Lusis AJ. Direct gene transfer into donor hearts at the time of harvest. J Thorac Cardiovasc Surg 1995;109:716-20.

3. Fyfe AI, Ardehali A, Laks H, Drinkwater DC, Lusis AJ. Biologic modification of the immune response in mouse cardiac isografts using gene transfer. J Heart Lung Transplant 1995;14:S165-70.

4. Dalesandro J, Akimoto H, Gorman CM, McDonald TO, Thomas $\mathrm{R}$, Liggit HD, et al. Gene therapy for donor hearts: ex vivo liposome-mediated transfection. J Thorac Cardiovasc Surg 1996;111: 416-22.

5. Lee J, Laks H, Drinkwater DC, Blitz A, Lam L, Shiraishi Y, et al. 
Cardiac gene transfer by intracoronary infusion of adenovirus vector-mediated reporter gene in the transplanted mouse heart. J Thorac Cardiovasc Surg 1996;111:246-52.

6. Bergelson JM, Cunningham JA, Droguett G, Kurt-Jones E, Krithivas A, Hong JS, et al. Isolation of a common receptor for Coxsackie B viruses and adenoviruses 2 and 5. Science 1997; 275:1320-3.

7. Mathias P, Wickam T, Moore M, Nemerow G. Multiple adenovirus serotypes use $\alpha \mathrm{v}$ integrins for infection. J Virol 1994;68: 6811-4.

8. Goldman MJ, Wilson JM. Expression of $\alpha_{\mathrm{v}} \beta_{5}$ integrins is necessary for efficient adenovirus-mediated gene transfer in the human airway. J Virol 1995;69:5951-8.

9. Chapelier A, Danel C, Mazmanian M, Bacha EA, Sellak H, Gilbert M-A, et al. Gene therapy in lung transplantation: feasibility of ex vivo adenovirus-mediated gene transfer to the graft. Hum Gene Ther 1996;7:1837-45.

10. Pellegrini C, O’Brien T, Jeppsson A, Fitzpatrick LA, Yap J, Tazelaar $\mathrm{H}$, et al. Influence of temperature on adenovirus-mediated gene transfer. Eur J Cardiothorac Surg 1998;13:599-603.

11. Ferrera R, Larese A, Marcsek P, Guidollet J, Verys M, Dittmar A, et al. Comparison of different techniques of hypothermic pig heart preservation. Ann Thorac Surg 1994;57:1233-9.

12. Okada K, Yamashita C, Okada M, Okada M. Successful 24-hour rabbit heart preservation by hypothermic continuous coronary microperfusion with oxygenated University of Wisconsin solution. Ann Thorac Surg 1995;60:1723-8.

13. Graham FL, Prevec L. Manipulation of adenovirus vectors. In: Murray EJ, editor. Methods in molecular biology. 1st ed. Clifton [NJ]: The Humana Press; 1991. p. 109-28.

14. Ono K, Lindsey ES. Improved technique of heart transplantation in rats. J Thorac Cardiovasc Surg 1969;57:225-9.

15. Billingham ME, Cary NR, Hammond ME, Kemnitz J, Marboe C, McAllister HA, et al. A working formulation for the standardization of nomenclature in the diagnosis of heart and lung rejection: Heart Rejection Study Group. The International Society for Heart Transplantation. J Heart Lung Transplant 1990; 9:587-93.

16. Brauner R, Wu L, Laks H, Nonoyama M, Scholl F, Shvarts O, et al. Intracoronary gene transfer of immunosuppressive cytokines to cardiac allografts: method and efficacy of adenovirus-mediated transduction. J Thorac Cardiovasc Surg 1997;113:1059-67.

17. Brauner R, Nonoyama M, Laks H, Drinkwater DC Jr, McCaffery $\mathrm{S}$, Drank $\mathrm{T}$, et al. Intracoronary adenovirus-mediated transfer of immunosuppressive cytokine genes prolongs allograft survival. J Thorac Cardiovasc Surg 1997;114:923-33.

18. Sawa Y, Kadoba K, Suzuki K, Bai H-Z, Kaneda Y, Shirakura R, et al. Efficient gene transfer method into the whole heart through the coronary artery with hemagglutining virus of Japan liposomes. J Thorac Cardiovasc Surg 1997;113:512-9.

19. Kass-Eisler A, Flack-Pedersen E, Alvira M, Rivera J, Buttrick PM, Wittenberg BA, et al. Quantitative determination of adenovirus-mediated gene delivery to rat cardiac myocytes in vitro and in vivo. Proc Natl Acad Sci U S A 1993;90:11498-502.

20. Guzman RJ, Lemarchand P, Crystal RG, Epstein SE, Finkel T. Efficient gene transfer into myocardium by direct injection of adenovirus vectors. Circ Res 1993;73:1202-7.

21. French BA, Mazur W, Geske RS, Bolli R. Direct in vivo gene transfer into porcine myocardium using replication-deficient adenoviral vectors. Circulation 1994;90:2414-24.

22. Yap J, O'Brien T, Tazelaar HD, McGregor CGA. Immunosuppression prolongs adenoviral mediated transgene expression in cardiac allograft transplantation. Cardiovasc Res 1997;35:529-35.

23. Kypson AP, Peppel K, Akhter SA, Lilly RE, Glower DD, Lefkowitz RJ, et al. Ex vivo adenovirus-mediated gene transfer to the adult rat heart. J Thorac Cardiovasc Surg 1998;115:623-30.

24. Shiraishi M, Kusano T, Hara J, Shao-Ping M, Makino Y, Muto Y. Adenovirus-mediated gene transfer using ex vivo perfusion of the heart graft. Surg Today Jpn J Surg 1996;26:624-8.

25. Donahue JK, Kikkawa K, Johns DC, Marban E, Lawrence JH. Ultrarapid, highly efficient viral gene transfer to the heart. Proc Natl Acad Sci U S A 1997;94:4664-8.

26. Donahue JK, Kikkawa K, Thomas AD, Marban E, Lawrence JH. Acceleration of widespread adenoviral gene transfer to intact rabbit hearts by coronary perfusion with low calcium and serotonin. Gene Ther 1998;5:630-4.

27. Pellegrini C, O’Brien T, Yap J, Jeppsson A, Tazelaar HD, McGregor CGA. Systematic evaluation of distribution of transgene expression after adenovirus-mediated gene transfer to the transplanted heart. Transplant Int 1998;11:373-7. 